075

Received: June 25, 2009

Accepted: November 15, 2009

\title{
TRITICALE IMPLEMENTATION IN NONRUMINANT ANIMALS NUTRITION
}

\author{
Vera Djekić, Milivoje Milovanović, Mirjana Staletić, Vladimir Perišić \\ Small Grains Research Center, 34000 Kragujevac, Serbia \\ veraraj@kg.ac.rs
}

\begin{abstract}
Cognition about chemical composition and nutritive values of the triticale grain as well as the effect of its applying in nonruminant animal nutrition were pointed out in this paper. Triticale showed high level of proteins in the grain (2-3\% more than wheat and $4 \%$ more than rye), with very beneficial amino acid composition, what is the reason for its usage in domestic animals nutrition. There are opinions that triticale is one of potentially most perspective species as nutrition, and examination of its nutritive values is necessary regard the fact that its growing is more and more higher nowadays. Based on that examination it is supposed to be suitable in domestic animals nutrition. Thanks to intensive plant breeding programs, there are many new, commercial, more yielding varieties, with series of desirable characteristics, which give their contribution this variety to become more attractive and spread on larger areas. These results will show if triticale has an advantage over other cereals and in which percentage it will have influence on further increasing of areas under this crop.
\end{abstract}

Key words: triticale; chemical composition; nutritive capacity; nutrition

\section{ПРИМЕНА НА ТРИТИКАЛЕ ВО ИСХРАНАТА НА НЕПРЕЖИВНИ ЖИВОТНИ}

\begin{abstract}
Цел на ова испитување беше да се проучи хемискиот состав и хранливата вредност на зрното од тритикалето, како и ефектот на неговата примена во исхраната на непреживните животни. Тритикалето покажа висока содржина на протеини во зрното (2-3\% повеќе од пченицата и 4\% повеќе од 'ржта), со многу погоден аминокиселински состав, што е причината за негова примена во исхраната на домашните животни. Се смета дека тритикалето е еден од најперспективните видови во исхраната и проучувањето на неговата хранлива вредност е неопходно, имајќи предвид дека неговото одгледување денес е сѐ помасовно. Базирајќи се на ваквата констатација, се претпоставува дека тоа е погодно во исхраната на домашните животни. Благодарение на интензивните селекциски програми, има нови комерцијални и многу поприносни сорти, со серија посакувани карактеристики, кои овозможуваат овој вариетет да биде поатрактивен и да се рашири на големи површини. Овие резултати ќе покажат дали и во кој процент тритикалето има предност во однос на другите жита и дали ќе има влијание за понатамошното зголемување на површините со оваа култура.
\end{abstract}

Клучни зборови: тритикале; хемиски состав; нутритивен капацитет; нутритивност

\section{INTRODUCTION}

Triticale, as one of the new very successful species of cereals has been developed by crossing durum wheat with rye in order to join positive characteristics of both parents. Triticale potential, grown under optimal conditions, as regards the yield was approximately similar to wheat potential, and was much higher than wheat potential under unfavorable growing conditions (Brown, 1983). Wheat and triticale comparison shows that triticale accumulates more nitrogen than wheat in the heading period and grain physiological matu- ration, what indicates that triticale is a more appropriate culture for growing on nitrogen poor soils. As species, it has important value on soils with marginal characteristics as dry or acid soils, and is also less demanding as regards the fertilizers and other preparations which take place in agronomy. Triticale presented high tolerance as regards the acid soils, as well as good productive results on sandy soils. Similar advantages were obtained as regards the aridity. Triticale was planted where corn did not prosper, as well as the areas with moderate climate. It could be said that it inherited very good up to excellent tolerance as regards the 
most important pathogens and small grains pests. Early stature, drought and aridity resistance, lower stem, high and stabile grain yield are just some of the triticale variety characteristics derived from wheat, as the second parent (Milovanović et al., 2006). Newer triticale varieties were mostly reaching the yield of the leading wheat cultivars, while they were surpassing rye varieties, barley and oat (Milovanović and Perišić, 2002; Milovanović et al., 1998; 2005a). Triticale presented high adaptability on local agro-ecological conditions, and it was influenced on stabile yield reaching.

In accordance with the literature data, there are significant variations in chemical composition and triticale nutritive values, which was the result of huge hybrids number with very different characteristics (Milovanović et al., 2005b). As regards chemical composition triticale is very similar to wheat, except the reduced sugar which is higher than in the wheat and closer to the level colloquial for rye (Varughese et al., 1996).

Triticale has been most implemented nowadays as nutrients in nonruminant animals nutrition, especially in pigs and poultry nutrition (Djekić et al., 2009a), and there is also a trend of its usage for silage (Coffey and Gerrits, 2009). Many investigations present that triticale successfully replaces corn, wheat or barley in animal nutrition without negative implications on domestic animals efficiency.

\section{BASIC INFORMATION ON TRITICALE AS A NUTRIENT}

Triticale is a very suitable nutrient for all animal kinds because it has high resource of energy. A very important parameter of economical relevancy is protein yield per surface unit. Pointed characteristics are important for the biological value and technological products quality dedicated as well for human nutrition as for domestic animals nutrition. The nutritive value of grain depends on the protein content in the grain, and therefore the quality of the product. Proteins with higher content of essential amino acids (lysine, tryptophane, cisteine + methionine, threonine, leucine, isoleucine, histidine, valine and phenylalanine) have a higher nutritive value, where the lysine content is the most important, as the first deficit amino acid on cereals. Triticale has higher percentage of protein and lysine as regards the parental species and lower energetic value as regards the wheat and maize (Mosse et al., 1988; Barneveld and Cooper, 2002).

The proteins nutritive value depends on the essential amino acids content (Kurkiev et al., 1975). The content of lysine in triticale could be the parameter of overall protein quality. As regards the lysine content triticale is much better than wheat. Significant variability as regards the proteins and lysine content on triticale, compared with wheat, indicate ability for further protein quality improvement on triticale, with selection continuance based on yield and grain quality. Considerate towards Halse (1974), some triticale lines have lysine content similar or equal to maize Opaque- 2 content. Hexaploide triticale was richer, in accordance with Cmeleva and Cikida (1988) with lysine than octoploid, while octoploid triticale has less alkylresorcinol. Researching variety Beagle 82 Hale et al. (1985) confirmed that it contains $0.48 \%$ of lysine. Myer et al. (1990) researching different varieties of triticale and different lysine contents found $0.48 \%, 0.43 \%$ and $0.41 \%$.

Contradictory data on the phenol content as an alkylresorcinol type (which makes triticale a nutritive value lower at nonruminant animals) are reached in different experiments (Milovanović et al., 2001). In accordance with the same authors, triticale overbid rye and wheat in the carotenoide content and also has lower content of crude filaments than rye. Tripsin inhibitors (known at soya been also) have important influence on the nutritive value decreasing and proteins exploitation. Triticale poses higher activity of trypsin inhibitors than wheat and similar as rye. Under thermal treatment $\left(98^{\circ} \mathrm{C}\right)$ their activity is ceased. Some triticale varieties present an advantage as regards the wheat.

In accordance with the literature data, there are different variations as regards chemical composition and nutritive characteristics of triticale, which is the result of a huge number of hybrids with huge spectrum of characteristics. Milovanović (1993) emphasizes that different winter triticale genotypes had fluctuated within the two years long period from 13.44 up to $16.42 \%$. Milovanović et al. (1995), at different winter triticale genotypes got within four years long period from 14.32 to $16.29 \%$ proteins on average, while winter wheat variety got 13.57 up to $13.70 \%$. The same authors pointed that spring triticale varieties had more proteins compared to winter ones. As regards the lysine content in proteins, triticale fluctuated within the range from 2.2 to $3.4 \%$, while there was fluc- 
tuation on wheat in the range of 1.7 to $2.1 \%$. Muhametov et al. (1996), emphasize that Russian triticale varieties content on an average is about $14.0 \%$ moisture, $12.8 \%$ proteins, $68.6 \%$ carbohydrates and $1.5 \%$ fats, while the proteins of the mentioned varieties content is on an average of 5$10 \%$ albumin, 6-7\% globulin and $30-37 \%$ of polyamine.

As regards the technological grain quality, in human nutrition, triticale is still beyond the wheat (smaller content and worst gluten quality), so it is mostly used for domestic animal nutrition (Çiftci et al., 2003). Leeson and Summers (1997) pointed that different triticale varieties content is $11-20 \%$ of crude proteins, while the structure of amino acids, as well as the energy level, is similar to wheat. According to Milovanović et al. (2001), the content of proteins at triticale fluctuates from 12 to $50 \%$, with triticale forms in which the content does not overbid the one at wheat. These occurrences are mostly found at hexaploide lines and especially at lines breed on higher productivity and grain plumpness. Experiments practiced in different countries presented that triticale grain, if it was not contaminated with ergot or fusarium, possesses similar nutritive values like wheat, and was superior to barley. Besides the desirable nutritive characteristics, new approved $\mathrm{KG}$ winter triticale varieties (Favorit), achieving also significantly higher productivity compared with the standard (Milovanović et al., 2006). Authors distinguish that the Favorit variety had high productivity and yield stability, while there was high content of proteins in the grain of high nutritive value. The grain of this variety is mostly used as a component for concentrated nutritive prepared for animal nutrition, based on high amino-acids content (lysine, methionine, tryptophan) and proteins. Milovanović et al. (1998, 2007a), describing the Kragujevac's "Knjaz" triticale variety emphasize that the average content of crude proteins in DM was $14.1 \%$, which was $1.2 \%$ higher than the standard (KG 20). Protein content in grain fluctuates at Kragujevac's varieties within the range of 14 to $17 \%$, while lysine content overbid commercial wheat cultivars for 10 to 30\% (Milovanović et al., 2001; 2007b). They also emphasize, for the KG Rubin cultivar that it has average ashes content in the grain $1.82 \%$ DM. Perišić et al. (2008) examined the "General" winter triticale variety. Compared with older varieties, General cultivars excel with higher and more stabile grain yielding. During two year period, the "General" variety realized statistically high, significant higher grain yielding compared with the standard KG 20 (5.770 kg/ha). Proteins content in the grain at the "General" variety was on the average of $14.6 \%$, while the ashes content was $1.72 \%$. Authors concluded that, as regards the high proteins content (14-17\%) and essentially amino-acids in the grain, the "General" variety presents an excellent component for the fodder mixture and fractionally or completely could replace other nutritive (maize, barley, oat). Djekić et al. (2009b) presented the chemical composition of two triticale cultivars KG 20 and Favorit. Investigations were carried out in the period from 2007 to 2008 in the Center for Small Grains in Kragujevac. The average protein content of the triticale cultivar KG 20 was $12.24 \%$ while the triticale cultivar Favorit had $12.55 \%$ of dry matter (DM). The average ash content of the cultivar KG 20 was $1.34 \%$ and in the Favorit $1.37 \%$ DM. The average water content observed in both triticale cultivars was about $11.35 \%$ DM. According to the cultivar effect on the average protein content, ash and moisture established differences were not statistically significant, $\mathrm{P}>0.05$.

Microtrial results of different triticale winter cultivars and perspective genotypes from the Small Grains Research Centre in Kragujevac during the period from 2003 to 2008. are presented in Table 1.

\section{Table 1}

Average values and variability of crude protein content in KG winter triticale cultivars and perspective genotypes from microtrial in Kragujevac during the period from 2003 to 2008

\begin{tabular}{lllll}
\hline \hline Cultivar/genotype & $\bar{x}$ & $\mathrm{~S}$ & $S_{\bar{x}}$ & $t$-exp \\
\hline KG 20 & 12.597 & 1.297 & 0.748 & - \\
Presto & 12.593 & 1.373 & 0.793 & 0.449 \\
$\operatorname{Tr} 350 / 3$ & 12.330 & 1.036 & 0.598 & 0.278 \\
Favorit & 13.870 & 1.063 & 0.614 & -1.315 \\
$\operatorname{Tr} 102 / 6$ & 12.957 & 2.844 & 1.642 & -0.200 \\
$\operatorname{Trijumf}$ & 11.970 & 1.341 & 0.774 & 0.582 \\
$\operatorname{Tr} 64 / 1$ & 12.177 & 2.140 & 1.235 & 0.291 \\
Žarko & 12.083 & 2.243 & 1.295 & 0.343 \\
$\operatorname{Tr} 339 / 4-3$ & 12.253 & 2.021 & 1.167 & 0.248 \\
$\operatorname{Tr} 71 / 5-2$ & 12.937 & 0.958 & 0.553 & -0.365 \\
$\operatorname{Vojvoda}$ & 12.750 & 1.316 & 0.760 & -0.144 \\
$\operatorname{Tr}$ 207/1 & 11.230 & 1.480 & 0.854 & 1.203 \\
$\operatorname{Tr} 55 / 3$ & 11.280 & 0.400 & 0.231 & 1.681 \\
$\operatorname{Tr} 110 / 3-2$ & 12.695 & 0.215 & 0.124 & -0.130 \\
Pobeda & 13.463 & 1.798 & 1.038 & -0.677 \\
\hline \hline
\end{tabular}


The recorded data from Table 1 points out that newer winter triticale cultivars and perspective genotypes have lower protein content in kernel than the check cultivar (KG 20), except Favorit, Vojvoda, $\operatorname{Tr} 102 / 6, \operatorname{Tr} 71 / 5-2$ and $\operatorname{Tr} 110 / 3-2$. Compared with wheat (Pobeda), they have lower protein content in kernel, except the cultivar Favorit $(13.87 \% \mathrm{DM})$. Examined triticale cultivars and perspective genotypes didn't shows significant difference of average values of protein content in kernel compared with the check cultivar KG 20 (P $>0.05$ ). Values of protein content from this period of investigation are significantly lower than values from the previous investigation (Milovanović et al., 1998, 2001, 2007a, 2007b; Perišić et al., 2008), which result from late sowing (29.X - 6.XII.), year conditions and decreased tendency of protein content in triticale because of continual selection pressure toward the increase of yield and better kernel plumpness.

According to the results gathered during five year examination of spring triticale cultivars and perspective genotypes from microtrials in the Small Grains Research Centre in Kragujevac, triticale protein content (Table 2) ranges from 13.074 to $14.694 \%$ DM. The examined spring triticale cultivars and perspective genotypes, except the genotype $\operatorname{Tr} 9 / 10-2$, had higher the average protein content compared to the check cultivar (Vojvoda $13.076 \%$ ). There is no statistical significance in the average values of protein content of examined spring triticale cultivars and perspective genotypes compared to the check cultivar. The average protein content in kernel of the cultivar Knjaz shows statistically significant difference compared to the check cultivar $(\mathrm{P}<0.05)$. This indicates that spring triticale genotypes have higher protein content than winter genotypes.

Based on the previously gained experimental results, wide production and statistical data sources it could be concluded that better results in small grain improving could be achieved with contemporary technology. New perspective triticale lines and varieties have more and better filled grains, higher yield, mass of hectolitre, while proteins and lysine were lower compared with older varieties (Myer et al., 1996; Milovanović et al., 2001). By breeding these properties at triticale, by total crude proteins decreasing, the content of lysine was increased (Mosse et al., 1988). Applying modern methods, small grains breeding will give new genotypes with higher yield genetically potential. Based on series advantages in producing technology and increased proteins content in grain, triticale took a more and more significant place in cereals production oriented for animal nutrition.

\section{Table 2} Average values and variability of crude protein
content in KG spring triticale cultivars and
perspective genotypes from microtrials in
Kragujevac during the period from 2003 to 2008

\begin{tabular}{lllll}
\hline \hline Cultivar/genotype & $\bar{x}$ & $\mathrm{~S}$ & $S_{\bar{x}}$ & t-exp \\
\hline Vojvoda & 13.076 & 0.735 & 0.328 & - \\
Soko & 13.098 & 0.752 & 0.336 & -0.553 \\
Delija & 13.282 & 0.259 & 0.116 & -0.591 \\
$\operatorname{Tr} 15 / 7$ & 13.314 & 0.481 & 0.215 & -0.606 \\
Knjaz & 14.694 & 1.094 & 0.489 & $-2.745^{*}$ \\
$\operatorname{Tr} 5 / 10$ & 13.280 & 1.568 & 0.701 & -0.263 \\
$\operatorname{Tr} 49 / 7-1$ & 13.600 & 4.438 & 1.985 & -0.260 \\
$\operatorname{Tr} 15 / 7-3$ & 13.134 & 0.835 & 0.373 & -0.117 \\
$\operatorname{Tr} 9 / 10-2$ & 13.074 & 0.806 & 0.361 & 0.004 \\
KG20 & 14.154 & 0.768 & 0.343 & -2.268 \\
Zlatar & 13.306 & 0.843 & 0.377 & -0.460 \\
\hline \hline
\end{tabular}

\section{TRITICALE APPLYING IN PIG NUTRITION}

Triticale is most in use as animal fodder. Many examinations present that triticale may replace successfully one part of maize, wheat or barley in fodder mixture bound for pigs nutrition without negative correlations on efficiency (Adeola and Young, 1985; Adeola et al., 1986; Myer et al. 1986; Huenke and Honeyman, 2001; Honeyman et al., 2001).

Some examinations presented equal or even better results on pig butchery characteristics when maize was replaced with triticale in fodder mixtures for feeding pigs nutrition (Hale et al., 1985), while other investigations presented performance reducing (Brand et al., 1995; Myer et al., 1989). Ability of triticale usage in pigs nutrition was investigated by Kovčin and Stanačev (2004). After literature data reviving they pointed that triticale could be involved in the fodder mixtures for feeding to piglets to $60 \%$ as regards the total cereals content. Further triticale increases in fodder mixtures grain to decreasing accession. There is also a high amount of trypsin and hemotrypsin inhibitors at older triticale cultivars, and it has bad influence on this nutritive usage in pigs nutrition. Alle and Hines (1972) had used the following portions in pigs fattening: 1 - Triticale; 2 - Triticale $+0.1 \%$ L-lysine; 3 - Triticale+soybean pellet; 4 - Sor- 
ghum+soybean pellet and 5 - Wheat+soybean pellet. They approved the smallest increasing under the usage of portion contained only triticale $(\mathrm{P}<0.05)$. They also suggest that it was the result of small lysine content as well as its small utilization. By half analyzing they deduced significant differences among the treatment in thickness of back bacon, half length, care area and fat parts percentage. Golushko and Marusich (1996) deduced significant increasing of digestible proteins and energy in nutrition of growing pigs. The influence of the triticale level in nutrition of decided piglets was examined by Erickson et al. (1979). Authors examined different triticale participation in the decided piglets nutrition in the following amounts: 0, 20, 40, 60, 80 and $100 \%$ per total cereals. Based on the gained results, they concluded that triticale increasing in the decided piglets nutrition over $60 \%$, lead to decreasing of accession, while the fodder consumption was bigger. But, if there was synthetic lysine in the mixture, it was possible to increase triticale up to $100 \%$, while the decreasing of accession is stopped and fodder consumption was bigger, but vindicated with a high cellulose share. In the very beginning of pigs fattening, triticale had similar nutritive properties as maize especially in the fattening finish. Mayer and Barnett (1996) gave an advantage to maize. Beside maize, triticale can successfully replace soybean flour in pigs fodder mixtures. Mayer and Barnett (2008) emphasizes that content of lysine amino acid in the pigs fodder mixtures was more important as regards the content of raw proteins, because, examining the mixtures with and without triticale at the same content of raw proteins, pigs fed with the mixture containing triticale had higher accession and meat slaughter yield. Sullivan et al. (2007) examined three groups of piglets fed in summer and winter months. The first group of pigs was fed with standard mixture without triticale content. The other one comprised $40 \%$ of triticale and the third $80 \%$ of triticale. Authors confirmed that the usage of nutritive consumption was higher during the summer months compared with winter months, and that was the less expensive at the group using $40 \%$ of triticale and had the least nutritive usage. The gained Canadian investigations in triticale applying in the pigs nutrition showed that triticale (Robertson et al., 1999) could replace barley in the mixtures for pigs nutrition of $25-110 \mathrm{~kg}$.

\section{TRITICALE APPLYING IN POULTRY NUTRITION}

Triticale has been commonly used for poultry nutrition all around the world (broilers, bearing hens). Poultry products quality could be modified or improved by triticale applying as nutrition in the animal nutrition portions, so there was a significant scientific interest in the triticale usage as nutritive, although the results in publicized works on this theme were poor, as regards the poultry productivity and meat and eggs quality, compared with the publications concerning this small grains influence on ruminants and pigs.

Investigations comprehend the influence of mixtures in broilers production with the different content of triticale on production results, quantitative and qualitative characteristics of broilers meat. A large number of scientists all around the world investigated the nutritive triticale values of production characteristics at heavy line hybrids (Ruiz et al., 1987; Johnson and Eason, 1988; Al-Athari and Guenter, 1989; Vieira et al., 1995), while there were not similar investigations in Serbia.

Barneveld and Cooper (2002) examined six triticale varieties in fodder mixtures for broilers fattening. Total nutritive consumption per one kilogram of chicken body mass was fluctuated from 1.75 up to $2.24 \mathrm{~kg}$. They emphasized that the triticale grain had higher protein content, lysine and methionine, while the digestion was the same like at the wheat and maize grain. Savage et al. (1987) pointed that triticale applying in chicken nutrition increases physical and sensor characteristics of broiled meat. Wheat replacing with triticale in the mixture didn't gain to changes on production and butchery chicken characteristics. Vohra et al. (1991) pointed that with the usage of triticale in the broiler fattening mixture we could solve the problem of commercial enzymes addition in fodder mixtures, which would also reduce the expenses in fodder production. Korver et al. (2004) gave an advantage to triticale as regards higher weekly broilers accession under the equal amount of intake nutritive. Hermes and Johanson (2004) warranted that triticale in nutrition of heavy line hybrids, in the different percentage of amounts in the mixture, did not present negative effects on chickens production characteristics. The biggest examined chicken body mass was achieved with $10 \%$ triticale participation in fattening broilers fodder mixtures, while the largest nutrition conversion was at mixture with $15 \%$ of triticale participation. Different formulations, as well as triticale and wheat participation in the fodder mixtures for broilers fattening were examined by Sarver et al. (2006). They concluded that the biggest body mass at the end of the investigation period was achieved 
by broilers fed with the following formulations: W40T60 and W60T40. The smallest mortality was improved at the group which was fed with the fodder mixture without triticale. Comparing triticale and wheat in the broilers nutrition, Savage et al. (1987) pointed that triticale introduced in the turkey nutrition gained to better meats quality as regards other nutrition ways.

Investigations in the consumption eggs production as regards different triticale formulations are mostly pointed at the eggs quality increase (albumen quality, cholesterol decreasing). A huge number of investigators investigated the ability of triticale applyed in light lines hybrids, respectively the eggs production (Maurice et al., 1989; Boros, 2002; McNab and Shannon, 1975; Flores et al., 1994; Fayez et al., 1996). They concluded that there was no difference in productivity, even if the bearing hens were supported only with triticale.

In Oregon, Boldaji et al. (1986) examined different triticale formulations in the fodder mixtures for bearing eggs hens. Based on the results they achieved, there was a conclusion that there were no significant differences in egg production, food consumption, internal or external egg quality characteristics, as well as the body mass as regards the hens which were fed with triticale and the controlling group. Bearing eggs hens which were fed with triticale had a little bit lighter yolk color as regards the eggs from the control group. The total nutritive consumption for one egg production was smaller at the group which was fed with mixture containing triticale as regards the hens of the control group, while the egg quality was the same. They determined that the triticale usage as an nutritive in the bearing eggs hens fodder mixtures depends on the current market price as regards the maize and if it was available on the market. In accordance with Karunaewa and Tham (1984) in the bearing eggs hens productions, triticale which replaced in the past different quantities of barley, did not present negative effects on the eggs production, while Leeson and Summers (1987) emphasize that higher proportions of triticale grain cause negative effects. According to Jokić et al. (2004), triticale could be involved in the portions for progeny and bearing eggs hens $5-15 \%$, and for the broilers up to $2 \%$. Higher triticale quantities are not desirable as regards the lysine deficit, and on the contrary synthetic lysine must be added.

The content of soluble pentozane in triticale is similar to the wheat and significantly lower in comparison to the rye (Petterson, 1988; Pena,
1996). The content of irresoluble pentozane is the highest at triticale $(6.6 \%)$, the lowest at wheat $(3.9 \%)$ and intermediary $(4.9 \%)$ in the rye (Petterson, 1988). Additional preparing with pentozane made significantly better performances at the chickens bred on rye or triticale. This increase was attached to endosperm cells walls distracting of enzymes, which resulted with more complete digestion in the chicken small intestine. Contradictory to the mentioned above, differing from maize, triticale does not contain yellow colored pigments (carotene and xanthophille). As the market showed higher requirements on chicken with yellow skin color and eggs with brown egg shell, in the fodder mixtures where triticale was present during the nutrition of broilers and bearing eggs hens, nutritives with higher percentage of pigments must be added, respectively maize flour and dehydrated lucerne (El Boushy and Raterink, 1992).

\section{CONCLUSION}

Triticale is a cereal species gained by crossbreeding of wheat and rye. Thanks to its nutritive values higher than maize, selectioneers and scientists for animal nutrition recommended it for all animal species nutrition. Also, it could replace wheat very successfully in portions for animal nutrition, as regards the fact that food demands in the world are larger and more, and wheat yields and soils area less and less. Triticale is especially characteristic as regards the high protein content in the grain and beneficial content of important amino acids as regards the other cereals.

An adequate content of proteins must be represented in portions of all nonruminat animals. The usage of too many proteins is irrational and not an economic measure, while deficit may cause less consumption and food usage, accession decreasing or meat production, as well as changes as regards the meat and eggs quality. Often these symptoms have been usually connected or they were going together with energy deficit and are the sign of inadequate nutrition at pigs and poultry. Also, the ratio between soluble and irresoluble proteins must be adequate so the maximal production results could be gained.

As regards everything what has been mentioned above it could be concluded that triticale as the youngest small grain cereal species took place in husbandry production, and with its quality found the place in the animal husbandry produc- 
tion. It has been more presented in the human nutrition, too. As regards all mentioned above, it earned one of the leading species positions in the future.

Acknowledgment, example: Results presented in this work are part of the Project No. TP 20063 examination "New technologies developing for small grain production improvement", financed by the Ministry of Sciences and Technological Development of the Republic of Serbia, in regards to what the authors are very grateful.

\section{REFERENCES}

[1] Adeola, O., L. G. Young (1985): Triticale in diets of growing pigs. J. Anita. Sci. 61 (Suppl. 1):309.

[2] Adeola O., Young L. G., Mcmillan E. G., Moran E. T., Jr (1986): Comparative Protein and energy value of oat winter triticale and corn for pigs. J. Anita. Sci. 63:18541861.

[3] Al-Athari A. R., Guenter W (1989): The effect of fat level and type on the utilization of triticale (cultivar Carman) by broiler chiks. Animal Feed Science and Technology, vol. 22, Is. 4, p. 273-284.

[4] Alle L. G., Hines G. G. (1972): Nutritional adequacy of triticale for finishing swine. Journal of Animal Science. 35, 5: 59.

[5] Barneveld R. J., Cooper K. V. (2002): Nutritional quality of triticale for pigs and poultry. Proc. of the $5^{\text {th }}$ International Triticale Symposium, vol. 1, 277-282, Poland.

[6] Belaid, A. (1994): Nutritive and economic value of triticale as a feed grain for poultry. CIMMYT economics working paper, 94-01. Mexico, D.F.: CIMMYT.

[7] Boldaji, F., Goeger, M. P., Nakaue, H. S., Arscott, G. H., T. F. Savage (1986): Apparent, true and nitrogen corrected metabolizable energy values of different varieties of triticale, wheat and barley in poultry. Nutr. Rep.Int. 33:499-503.

[8] Boros, D. (2002): Physico-chemical indicators suitable in selection of triticale for high nutritive value. In: E. Arseniuk, ed. Proc. 5th Int. Triticale Symp., Radzikow, Poland, Plant Breeding and Acclimatization Institute, 30 June - 5 July 2002, Vol. I, p. 239.

[9] Brand, T. S., Olckers, R. C., Van Der Merwe, J. P. (1995): Triticale (Tritico secale) as substitute for maize in pig diets. Animal Feed Science and Technology, 53, 345-352.

[10] Brown J. C., Graham J. H. 1978: Requirementes and tolerance to elements by alfalfa. Agronomy Journal, 70, 367-373.

[11] Čmeleva, Z. V.; Čikida, N. N. (1989): Nauč-tehn. Bil. BNII rasteniev. 195, 54-57.

[12] Çiftci, I., Yenice, E., Eleroglu, H. (2003): Use of triticale alone and in combination with wheat or maize: effects of diet type and enzyme supplementation on hen performance, egg quality, organ weights, intestinal viscosity and digestive system characteristics, Animal Feed Science and Technology, 105, 149-161.

[13] Coffey M. T., Gerrits W. J. (2009): Digestibility and feeding value of b858 triticale for swine. J. Anim. Sci. 66: $2728-2735$.
[14] De Brum P. A. R., Zannoto D. L., Gvidoni A. L., Rosa P. S., De Lima G. J. M. M., Viola E. S. (2000): Triticale in diets for broilers. Pesquisa Agropecuaria Brasileira, Vol. 35, Is. 2, p. 229-239.

[15] Djekić V., Milovanović M., Glamočlija Dj., Staletić M, (2009a): Possibilible implementation of triticale in poultry nutrition. Proceedings of XXIII ${ }^{\text {th }}$ Conference of Agronomist, Veterinarians and Technologists, Proceedings of Research Papers, Vol. 15, No. 1-2, p. 39-48, Belgrade.

[16] Djekić V., Staletić M., Perišić V., Glamočlija Dj. (2009b): Hemical composition of triticale cultivars from Kragujevac in period 2007-2008. XIV th $^{\text {Conference of }}$ Biotechnology with the international participation. Proceedings of Research Papers, vol. 14 (15), p. 73-77, Čačak.

[17] El Boushy, A. R., Raterink, R. (1992): Egg yolk pigmentation. World Rev. Anim. Prod., 27: 50.

[18] Erickson J. P., Miller E. R., Elliott F. C., Ku P. K., Ullrey D. E. (1979): Nutritive evaluation of triticale in swine starter and grower diets. Journal of Animal Science, 48: 547-553.

[19] Fayez, El-Yassin, Haj-Omar Nedal, Abboud Mousa. (1996): Nutritive value and feed efficiency of broiler diets containing different levels of triticale. In: H. GuedesPinto et al., Triticale: Today and tomorrow, Pub Kluwer Academic Publishers, Netherlands, 819-826.

[20] Flores, M. P., J. I. R. Castanan, J. M. Mcnab. (1994): Effect of enzyme supplementation of wheat and triticale based diets for broilers. Anim. Feed Sci. and Technol. 49: 237-243.

[21] Golushko V. M., Marusich A. G. (1996): Triticale feed mixtures for finishing young pigs. Vestsi Akademii Agrarnikh Navuk Belarusi, 2, 64-67.

[22] Hale O. M., Morey D. D., Myer R. O. (1985): Nutritive value of beagle 82 triticale for swine. Journal of Animal Science, Vol. 60, No. 2, p. 503-510.

[23] Halse, H. D. (1974): Тритикале - первая зерновая культура, созданная человеком. Kolos, 19-25, Moskva.

[24] Hermes J.C., Johanson R.C. (2004): Effects of Feeding Varios Levels of Triticale var. Bogo in the Diet of Broiler and Layer Chickens. Journal of Applied Poultry Research, 13, 4, ProQuest Agriculture Journals, pg. 667-672.

[25] Honeyman, M. S., Harmon, J. D., Kliebenstein, J. B., Richard, T. L. (2001): Feasibility of hoop structures for market swine in Iowa: Pigs performance, pig environment, and budget analysis. Applied Engineering in Agriculture, 17 (6), 869-874.

[26] Huenke, L., Honeyman, M. S. (2001): Fecal Weber content of wishing pigs in hoop structures and con Wnement. Swine Research Report. AS-646. ISU Ext. Ser., Ames, IA.

[27] Johnson, R., P. Eason. (1988): Evaluation of triticale for use in meat-type chickens. J. Sci. Food Agric. 42: 95108.

[28] Jokić Z, Kovčin S., Joksimović-Todorović M. (2004): Nutrition of poultry. University of Belgrade, Faculty of Agriculture, Belgrade-Zemun.

[29] Korver D. R., Zuidhof M. J., Lawes K. R. (2004): Performance Characteristics and Economic Comparison of Broiler Chickens Fed Wheat and Triticale-Based Diets. Poultry Science, 83 (5), 716-725.

[30] Kovčin, S., Stanačev, V. (2004): Triticale in the nutrition of pigs. Acta Agriculturae Serbica, 9 (17), 625-631. 
[31] Leeson, S., J. D. Summers. (1987): Response of White Leghorns to diets containing ground or whole triticale. Can. J. Anim. Sci. 67: 583-585.

[32] Maurice, D. V., J. E. Jones, Lightsey, S. F., Rhoades, J. F., K. T. Hsu. (1989): Chemical composition and nutritive value of triticale (Florida 201) for broiler chickens. Applied Agric. Res. 4: 243-247.

[33] Mcnab, J. M., Shannon, D. W. F. 1975: The nutritive value of triticale and rye for the laying hen. British Poultry Sci. 16: 9-15.

[34] Milovanović, M. (1993): Investigation of yield and technological traits of grain of the intergenus hybrids triticale (X Triticosecale Wittmack). Rewiew of Research Work at the Faculty of Agriculture, Zemun-Belgrade, 38, 2; 7182.

[35] Milovanović, M., Pavlović, M., Kuburović, M., Jestrović, Ž. (1994): Productivity and some important agronomic traits of winter triticale. J. Sci. Agric. Res., 55, (200), 4; 57-65.

[36] Milovanović, M., Kuburović, M., Stojanović, S., Ognjanović R. (1995): Some recent results of winter triticale breeding in Kragujevac. 1st Balkan Symposium "Breeding and cultivation of wheat, sunflower and legume crops", Albena-IWS, Bulgaria, Proceedings, 125-129.

[37] Milovanović, M., Kuburović, M. Stojanović, S., Kovačević, B. (1998): Some results of investigations and winter 6x triticale breeding in Kragujevac. Intern. Symp. "Breeding of Small Grains", Kragujevac, Yugoslavia, Proceedings, 225-231.

[38] Milovanović, S. M., Rigin, V. B., Xynias, N. I. (2001): Genetic and breeding studies on triticale (X Triticosecale Wittmack). In: Genetics and breeding of small grains. ARI Serbia, 235-298, Belgrade.

[39] Milovanović, S. M., Perišić, D. V. (2002): Results and future prospects for winter triticale breeding in Yugoslavia. Proc. of the $5^{\text {th }}$ Intern. Triticale Symp., Vol. 1, 229-236, Poland.

[40] Milovanović, M., Perišić, V., Mirjana Staletić (2005a): Some additional aproaches in production of spring triticales. Contemporary Agriculture, 3-4, 374-380, Novi Sad.

[41] Milovanović, M., Perišić, V., Mirjana Staletić (2005b): Possibilities for growing of some facultative triticale cultivars. Contemporary Agriculture, 1-2, 125-129, Novi Sad.

[42] Milovanović, M., Perišić, V., Staletić Mirjana (2006): Favorit - new vinter triticale cultivar for intensive growing conditions. A Collection of Articles from the Technical Vocational College in Požarevac, 1-2, 93-97.

[43] Milovanović, M., Perišić, V., Mirjana Staletić, Jelena Milivojević, Snežana Živanović-Katić, Vera Djekić (2007a): Variety of Winter Triticale Knjaz. A Collection of Articles from the Technical Vocational College in Požarevac, 1, 13-18.

[44] Milovanović, M., Perišić, V., Vera Djekić, Vesna Stevanović (2007b): KG Rubin - New Triticale Cultivar. A Collection of Articles from the Technical Vocational College in Požarevac, 1, 19-23.

[45] Mosse, J.; Heuet, J.C., Baudet, J. (1988): The amino acid composition of triticale grain as a function of nitrogen content: Comparison with wheat and rye. J. of Cereal Sci., 7, 49-60.
[46] Muntzing, A. (1979): Triticale, resuls and problems. In: Advances in Plant Breeding, Z. Pflanzenzucht Suppl. 10, Verlag Paul Parey Berlin and Hamburg, pp. 1-103.

[47] Myer, R. O., Barnett, R. D., Combs, G. E. (1986): Evaluation of 'Florida 201' triticale as a feed grain in swine diets. Soil and Crop Science Society of Florida, Proceedings, 46.

[48] Myer, R. O., Combs, G. E., Barnett, R. D. (1990): Evaluation of three triticale cultivars as potential feed grains for swine, Soil and Crop Science Society of Florida, Proceedings, 49, 155-158.

[49] Myer, R. O., Brendemuhl, J. H., Barnett, R. D. (1996): Crystalline, lysine and threonine supplementation of soft red winter wheat or triticale, low-protein diets for growingwishing swine. Journal of Animal Science, 74, 577-583.

[50] Myer R. O., Barnett R. D. (2008): Triticale Grain in Swine Diets. Reviewed March 2008. Visit the EDIS Web Site at http://edis.ifas.ufl.edu.

[51] Pena, R.J. (1996): Factors affecting triticale as a food crop. In: H. Guedes-Pinto, N. Darvey \& V.P. Carnide (eds), Triticale: today and tomorrow. Kluwer Academic Publishers, London, pp. 753-762.

[52] Perišić, V., Milovanović, M., Bratković, K. (2008): New Cultivar of Winter Triticale-General. A Collection of Articles from the Technical Vocational College in Požarevac, 1-2, 59-64.

[53] Pettersson, D. (1988): Composition and productive value for broiler chickens of wheat, triticale and rye. Disert., Sveriges Lantbuksuniverrsitet, Swedish Univ. of Agric. Sci., Report 177, Uppsala.

[54] Robertson, W. M., Jaikaran, S., Jeremiah, L. E., Salmon, D. F., Aherne, F.X., Landry, S. J. (1999): Meat quality and palatability attributes of pork from pigs fed corn, hulless barley or triticale diets. Advances in Pork Production, 10, 35 .

[55] Ruiz, N., Marion, E., Miles, R. D., R. B. Barnes. (1987): Nutritive value of new cultivars of triticale and wheat for broiler chick diets. Poultry Sci. 66: 90-97.

[56] Sarker, N. R., Haque, M. E., Haque, K. S., Haque, Q. M. S., Waddington, S. R. (2006): Triticale fodder and grain utilization by dairy cattle and poultry in Bangladesh. International Maize and Wheat improvement Center (CIMMYT), Uttara, Dhaka-1230, Proc. of the $6^{\text {th }}$ International Triticale Symposium, p. 108-113.

[57] Savage T. F., Holmes Z. A., Nilipour A. H., Nakaue H. S. (1987): Evaluation of cooked breast meat from male breeder turkeys fed diets containing varying amounts of triticale, variety Flora. Poultry Sci. 66: 450-452.

[58] Sullivan Z. M., Honeyman M. S., Gibson N. M., Ken P. J. (2007): Effects of the child based on triticale unishing pig performance and pork quality in deep-bedded stalls ring. Meat Science, 76, 428-437.

[59] Varughese, G., Pfeiffer, W. H., Peňa, R. J. (1996): Triticale: A Successful Alternative Crop (Part 1), Cereal Foods World, 41, 6, 474-484.

[60] Vieira, S. L., Penz, A. M., Kessler, A. M., Catellan. E. V. (1995): A nutritional evaluation of triticale in broiler diets. J. Appl. Poultry Res. 4: 352-355.

[61] Vohra, P., S. Bersch, C. Q. Qualset, R. Baker (1991): Triticale: Alternative cereal grain in broiler starter diets. Calif. Agric. 45:34-37. 